This PDF is a simplified version of the original article published in Internet Archaeology. All links also go to the online version.

Please cite this as: Matskevich, S. and Weinblum, L. 2021 Digital Archaeological Archiving in Israel, Internet Archaeology 58. https://doi.org/10.11141/ia.58.10

\title{
Digital Archaeological Archiving in Israel
}

\author{
Sveta Matskevich and Liat Weinblum
}

\section{Summary}

In this article, the authors present two points of view on the preservation and dissemination of archaeological data in Israel: an official version of the policy makers (the Israel Antiquities Authority, henceforth IAA), and the view from the archaeological, especially academic, community outside the IAA. This includes an assessment of the strategies undertaken (or not) over the last $40+$ years resulting in the majority of data being inaccessible, and documenting significant data loss since the 1990s. This is followed by current work to address these issues, including not only efforts to digitise but misconceptions about the problems digitisation both solves and creates, along with recommendations for how to approach the issues going forward.

\section{Introduction}

As in many other Near Eastern counties that suffered from heavy looting of antiquities in the 18th and 19th centuries, archaeology in Israel is regulated at the state level in accordance with an Antiquities Law, which is a successor to the Ottoman Antiquities Law of 1884 and is based on the regulations regarding antiquities declared by the British Mandate in 1918 and 1933-35. The law, enacted in 1978 (in Hebrew/ English) and subjected to numerous amendments since then, provides the definition of an archaeological site, as well as regulations regarding legal and illegal actions related to the sites and antiquities, including excavation, preservation, looting, and sales. The statutory body responsible for the execution of the Antiquities Law is the Israel Antiquities Authority, an independent governmental body established in 1990 as an enlarged and reformed version of the Israel Department of Antiquities and Museums (IDAM) that existed from 19481. The 1989 Israel Antiquities Authority Law (in Hebrew / English) defines the functions of the IAA and the powers of its controlling body, the IAA Board of Directors.

Every excavation and survey conducted in the country must be approved by the IAA Licence Committee. The current licensing policy is defined in accordance with the recommendations of the Archaeological Council. Preference is given to endangered 
sites and thus to salvage excavations. These are mainly conducted by the IAA, although in recent years also by accredited private Cultural Resource Management (CRM) companies affiliated with the archaeological departments of the local universities. A research-orientated excavation licence can be granted to a faculty member of an academic institution, ${ }^{2}$ who holds at least an MA degree in archaeology and can prove sufficient field experience in Near Eastern archaeology. By signing a licence application, the institution takes full responsibility for the fulfilment of the Antiquities Law and assumes the obligation to provide storage and research facilities during the study and preparation of the publication. Starting from the early 1990s, museums no longer applied for excavation licences; curators of the archaeological collections (e.g., of the Israel Museum, Eretz-Israel Museum) rarely participate in excavations related to their research interests.

\section{Archaeological Archives}

The Antiquities Law requires submission of the field documentation ('annual report') to the Israel Antiquities Authority at the end of each excavation season (Antiquities Law C.12). During the last decade, this requirement is strictly fulfilled, as it is compulsory for licence renewal. The IAA, as a body responsible for 'concentration, documentation and registration of archaeological information' (Israel Antiquities Authority Law 5b[10]), preserves the annual report and other types of documentation (see below) in its Scientific Archive, which is one of the authorised archives for the country (according to the Archives Law).

\subsection{IAA archives}

The IAA manages several archives of an administrative and scientific nature (see Table 1):

- Scientific Archive

- Archive of the Survey Department

- Archive of the Conservation Department

- District Inspection Files

- Administrative Archive

- Plans and Field Drawings Collection

- Visual Collection (photo archive)

- Private Legacies

Additionally, the IAA oversees the archive of the Department of Antiquities of the British Mandate in Palestine (1921-48) $\stackrel{3}{\text {. }}$

Table 1: Accessibility (physical and digital) of the archives of the Israel Antiquities Authority

\section{Accessibilit}

Archive

y of
physical

Digitisatio

n
Accessibility of digital collections to the general public 
Scientific

Archive

Open In progress Unavailable

Archive of the

Survey

Open

Department

http://survey.antiquities.org.il/index Eng.html\#

Archive of the

Conservation Open

Department

Unavailable

District

Inspection Closed In progress Unavailable

Files

Administrativ

e Archive

Closed

All scanned Available for internal use

Plans and

Field

Drawings

Open In progress Available for internal use

Collection

Archive of

Department

of Antiquities

of the British

Open

All scanned http://www.iaa-archives.org.il/

Mandate in

Palestine

(1921-48)

$\begin{array}{llll}\begin{array}{l}\text { Visual } \\ \text { Collection }\end{array} & \text { Open } & \begin{array}{l}\text { Digitisation } \\ \text { in progress }\end{array} & \text { Unavailable } \\ \begin{array}{l}\text { Private } \\ \text { Legacies }\end{array} & \text { Open } & - & \text { Unavailable }\end{array}$

The Scientific Archive is the core section that contains the excavation records of the licenced excavations in the country since 1948. At the moment, the collection comprises c. 10,000 files, representing $70 \%$ of the issued licences. The Plans and Field Drawings Archive contains c. 12,000 inked drawings. It is worth noting that only about $40 \%$ of all excavations conducted in Israel are published, so for the remaining $60 \%$ these records are the only existing information about the site and its artefacts.

\subsubsection{Access}

The archives are open to the public in compliance with the Public Information Act of 1998. Some restrictions exist owing to exclusive rights of publication that the excavator holds for ten years from the date of completion of the excavation (Antiquities Law 
$3.12[b])$. During this time, excavation files can be accessed only with the permission of the excavator.

\subsection{Other archives}

- Institute of Archaeology, the Hebrew University of Jerusalem (HUJI)

- Israel Exploration Society (IES)

- Jerusalem Islamic Waqf

- French School of Biblical and Archaeological Research (École Biblique)

- Kenyon Institute (Council for British Research in the Levant; CBRL)

- W.F. Albright Institute of Archaeological Research

Archaeological institutions in the country, mostly situated in Jerusalem, keep archives of varying extent and orientation. For instance, the Hebrew University of Jerusalem and the IES archives, housed together at the Institute of Archaeology, contain mainly administrative records concerning archaeological activities in the country before and after establishment of the State of Israel. The École Biblique owns an enormous collection of photographs of archaeological sites, while the Waqf archive keeps unique records of the excavations conducted at Haram esh-Sharif/the Temple Mount from the 19th century onwards.

Additionally, relevant materials can be found in the State Archive (private legacies), and the Yad Ben-Zvi Archive.

\subsubsection{Access}

Accessibility of these archives varies from completely closed to the public to open for research.

Table 2: Accessibility (physical and digital) of archaeological archives of various institutions

\begin{tabular}{|c|c|c|c|}
\hline Archive & $\begin{array}{c}\text { Accessibility } \\
\text { of physical } \\
\text { material }\end{array}$ & $\begin{array}{l}\text { Digital } \\
\text { archive }\end{array}$ & Accessibility of digital collections \\
\hline $\begin{array}{l}\text { Institute of } \\
\text { Archaeology, the } \\
\text { Hebrew } \\
\text { University of } \\
\text { Jerusalem }\end{array}$ & Open & $\begin{array}{l}\text { Work in } \\
\text { progress }\end{array}$ & $\begin{array}{l}\text { Slide collection is available in the } \\
\text { HUJl domain; the rest is unavailable }\end{array}$ \\
\hline $\begin{array}{l}\text { Israel Exploration } \\
\text { Society (IES) }\end{array}$ & Open & $\begin{array}{l}\text { Work in } \\
\text { progress }\end{array}$ & Unavailable \\
\hline $\begin{array}{l}\text { French School of } \\
\text { Biblical and } \\
\text { Archaeological }\end{array}$ & Closed & $\begin{array}{l}\text { Scanned but } \\
\text { mostly } \\
\text { uncatalogued } \\
\text { collection }\end{array}$ & Unavailable \\
\hline
\end{tabular}




\begin{tabular}{|c|c|c|c|}
\hline $\begin{array}{l}\text { Research (École } \\
\text { Biblique) }\end{array}$ & & & \\
\hline $\begin{array}{l}\text { Kenyon Institute } \\
\text { (CBRL) }\end{array}$ & Closed & Unknown & \\
\hline $\begin{array}{l}\text { W.F. Albright } \\
\text { Institute of } \\
\text { Archaeological } \\
\text { Research }\end{array}$ & Open & Unknown & \\
\hline State Archive & $\begin{array}{l}\text { Temporarily } \\
\text { closed }\end{array}$ & $\begin{array}{l}\text { Digitisation in } \\
\text { progress }\end{array}$ & $\begin{array}{l}\text { Digitised materials are open } \\
\text { access: https://www.archives.gov.il/ }\end{array}$ \\
\hline Yad Ben-Zvi & Open & $\begin{array}{l}\text { Digitisation in } \\
\text { progress }\end{array}$ & $\begin{array}{l}\text { Photographs are available } \\
\text { at http://www.israelalbum.org.il/ }\end{array}$ \\
\hline
\end{tabular}

The first born-digital materials were submitted to the IAA Archive in the early 1990s, with the introduction of databases into field recording ${ }^{4}$. Initially, this 'exotic' media was left in the folders with the paper documents (and is still there...). According to the guidelines for depositing excavation files in the archive, published in 2004 , only photographs could be submitted digitally, all other documents were accepted in hard copy format only. A collection of CDs started to accumulate; their content was checked and, from some point on, copied to a designated directory on the server. The guidelines did not instruct the depositor which formats can or cannot be submitted; metadata requirements were missing as well 5 . In the 2010 s, as CD-ROMs became outmoded, the common practice became to send an electronic (PDF) and a hard copy of the file.

Assessment of the distribution of the paper and digital records in the scientific archive shows three groups:

- 1948-1992 - paper documentation only

- 1993-2010 - mixed paper and digital records

- 2011-present - fair or significant amount of fully digital excavation files

The digitisation process initiated recently will produce enormous amounts of data, for which neither storage facilities nor management systems have yet been planned.

\subsection{User experience}

\subsubsection{Data depositors from outside the IAA}

More than one hundred licences are issued annually for research-orientated excavations affiliated with local and foreign academic institutions and for salvage excavations 
conducted by CRM companies. Today, and during the last two decades, a site director, obliged to submit a hard copy of an excavation file at the end of the season, follows one of these three scenarios:

- Excavations with paperless recording capture all the data, accumulate it in a single PDF file, add a written report and print it out for submission. The PDF file may be sent to the archive, where it will end up on a server, having lost nearly all of its reuse potential.

- Paper records get scanned and then printed again, along with the digital records (spreadsheets, database forms and photos). The printed copy is submitted.

- Paper records are copied on a copy-machine, digital photographs are printed, and everything is bonded into an excavation file.

Records in digital format, submitted on a voluntary basis, mostly comprise photographs (c. $80 \%$ of the volume), text (c. $10 \%)$, tabular and other data types (10\%).

The end-of-season archiving is a relatively minor issue, since between the seasons and during the publication process the projects use, produce, and continue to support their data. The more severe problem is archiving at the end of the project, which either does not happen at all or includes only paper records. The remaining data are not sent to the archive, but are left behind on project hard-drives, and soon forgotten. There is a growing body of exceptions, however, regarding datasets related to specific research projects. While these are not properly archived, they are uploaded to a repository, where they can obtain a DOI to comply with the publisher's requirements. Several aspects are problematic here. The datasets are derived from the excavation project databases (e.g. a bone assemblage from one of the excavation areas, or 3D models of a specific type of vessel). They are understandable within the context of the published study, but they do not link back to the excavation context, and reverse links from the excavation database/website/reference collection rarely exist. In the case of Israel, where the institutional depositories are at the planning stage, Zotero is a recommended solution for researchers that need to make their published datasets accessible.

Even more rare are cases of proper deposition of archaeological digital data in a trusted, open repository. To date, datasets from five projects based on Israeli archaeological sites are published with Open Context $\underline{6}$. Four of them are specialist datasets, and only one (Sharon 2019) includes excavation records, deposited after the publication of the final report.

\subsubsection{Depositing data within the IAA}

The IAA conducts about 300 salvage excavations annually, while the size of the projects varies from $5 \times 5 \mathrm{~m}$-metre probe trenches to 'mega projects' exposing tens of thousands of square metres during several years of continuous digging?

The first type of born-digital data that enjoyed proper storage on optical media were visual records (photographs and field drawings). In the next stage (around 2003), these were moved to a storage server and the photographs were uploaded to the centralised IAA database system ('MENORA'). No other types of digital records were deposited; excavation data was stored as paper documents (mostly printed from digital originals). 
Starting from 2014, with the implementation of the official IAA excavation database DANA $\stackrel{8}{\circ}$ excavation records are now deposited digitally. The records are exported in PDF format and uploaded to cloud data storage, according to the excavation licence number and the submission date (e.g., IAA_8749_15102020). The storage is not linked to MENORA and has no file management system of its own.

\subsubsection{Data reuse outside the IAA}

From a development-led or academic-research point of view, data retrieval and reuse is difficult, if not impossible. An archaeologist seeking information about a site has no access to its inventory (available for internal use of IAA employees only; see below). The British Mandatory Archive online is a good point to start (if the relevant materials are already online), but for the later history of site exploration one needs to contact the archivist and hope for cooperation. In many cases, this is the first step in a long journey involving several institutions, people who (barely) remember information about the resource, or where resources are located in storage rooms, etc.

Even in the case of digitised records, the data management is in an FFF (Far From FAIR) state. The online Mandatory Collection is not indexed by search engines, and is therefore not findable. All other collections are unavailable to the public. Since there is no repository for the data, the level of their accessibility is irrelevant. Controlled vocabularies used by the IAA to describe the data in a standardised way are closed, therefore all data providers external to the Israel Antiquities Authority use their own terminology. As a result, apart from the very basic terms common in Israeli archaeology (Matskevich 2015, 12-46), there is no professional language accepted by the entire community, and the records submitted to the archive are not interoperable. Reusability of the data is doubtful as well. The records submitted by the various academic institutions do not follow any file-naming conventions or standards in file formats; most of the records are flattened to PDF. The IAA records are more standardised, but are deposited in a native proprietary format, and the only reusable data are in the exported PDF files.

\subsubsection{Data reuse within the IAA}

Despite the digital records of the IAA being disconnected islands of data, the task of finding information about a site is relatively easy for IAA employees, as they are able to access the monument and site records in the MENORA database. With the basic data (site number, licence number) in hand, one can explore relevant collections of digital and paper records. More sophisticated searches involve the use of the IAA thesaurus (available only within the IAA as well).

\section{Conclusions}

The archaeological community of Israel has accumulated digital records from the early 1990s. After 30 years without a strategy for managing the digital records in the archives of the Israel Antiquities Authority, the situation can be assessed as follows: $c$. $70 \%$ of the non-current portable media can be accessed and the data retrieved. As for data preservation, while the records of the last two decades are mostly legible and can be migrated to stable formats, at least $50 \%$ of the records from the 1990 s are lost 9 . 
Currently, several archaeological archives are undergoing digitisation and beginning to accumulate large amounts of digital data. In most of these cases, the stakeholders are not aware of the necessity for long-term preservation and stewardship of this data. In fact, this apparent step forward creates a frightening situation, when digitising is misunderstood as a solution for a storage problem ('what was scanned can now be discarded'), and at the same time, it is mistaken for digital preservation ('put it on the Internet and it will be fine'). These misconceptions put the archaeological community in danger of the total loss of archaeological knowledge collected for decades.

The major improvement, therefore, will be possible when the digitising project as a means of preserving a physical documentary archive approach will be upgraded to a creating a digital collection approach. Meanwhile, in order to begin mitigating the abovementioned frightening situation, it is highly recommended to operate in three directions (in this order):

- Establishing an archaeological digital archive. It would be most natural to have such a repository under the auspices of the IAA, whose paper archive is undergoing digitisation. Two major issues here are raising awareness about digital preservation, and appreciation of the uniqueness of the archives of the Antiquities Authority (and the non-repeatable nature of archaeological excavation). The urgency of this step cannot be overestimated, as the amount of digital data is growing steadily.

- Working with the local archaeological community. There are several psychological issues that lead to the neglect of data preservation. First, the sheer abundance of archaeological data creates a disservice to this very data; the sites, the finds and the records are often neglected because there are so many of them and the problem seems too insurmountable to deal with. Another problem is that the generation of scholars who undertook excavations over the previous several decades, and publish their reports today, see the final report as the ultimate answer to all questions raised by the excavation, and do not see the necessity for digital data preservation and accessibility.

- Introduction of obligatory digital archiving. This step should come when the infrastructure and the community are ready for it. Needless to say, the obligations will need to be mutual: the archive will need to be committed to long-term preservation of the deposited data at the same time that the deposition of this data will need to be mandatory.

To summarise, the current state of affairs in digital preservation of archaeological data is extremely fragile, and the danger of losing the data of two to three decades of fieldwork and post-excavation research is very real. The growing body of digital records requires immediate attention that will ensure its sustainability and accessibility. While the legal basis for creating a state archaeological digital archive exists, urgent actions need to be taken for building the infrastructure and educating the archaeological community, adopting best practices in digital preservation accumulated in other countries.

\section{Footnotes}

\footnotetext{
1. The Department was established in June 1948, right after the declaration of the State of Israel, as a direct successor of the Department of Antiquities of the British Mandate. For the

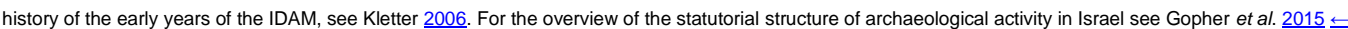




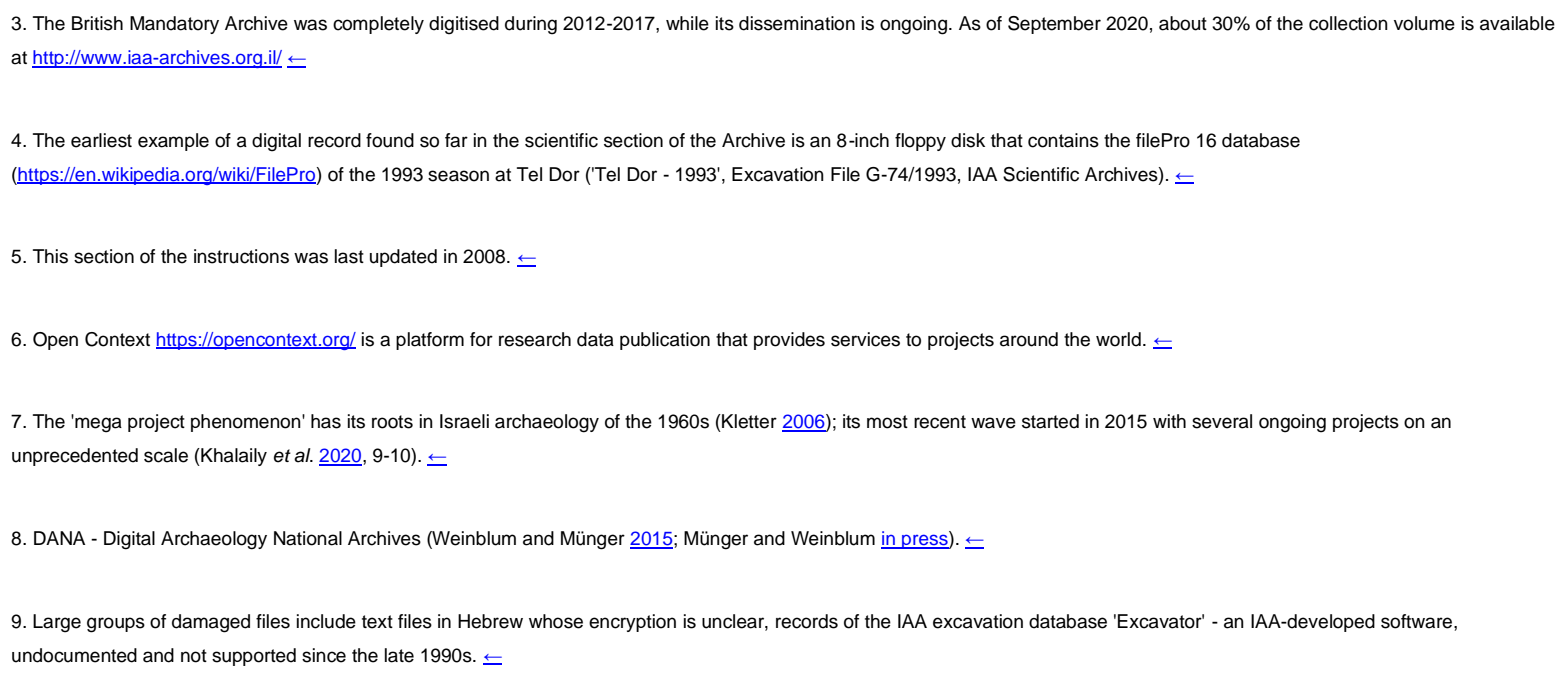

Gopher, A., Greenberg, R. and Herzog, Z. 2005 'Archaeological public policy' in D. Korn (ed) Public Policy in Israel, Lanham: Lexington Books. 191-204.

Khalaily, H., Re'em, A., Vardi, J. and Milevski, I. 2020 'Foreword: the Motza (Moża) excavations and beyond' in H. Khalaily, A. Re'em, J. Vardi and I. Milevski (eds) The Mega Project at Motza (Moza): The Neolithic and Later Occupations up to the 20th Century, Jerusalem: Israel Antiquities Authority. 9-

18. https://doi.org/10.2307/j.ctv1b9f5bh.3

Kletter, R. 2006 Just Past? The Making of Israeli Archaeology, London: Equinox.

Matskevich, S. 2015 'Off the Record'. Recording Systems for Archaeological Excavations in the Levant: Past and Future, Unpublished PhD thesis, The Hebrew University of Jerusalem. https://www.academia.edu/32320876/Off the Record Recording Systems for Archaeological Excavations in the Levant Past and Future

Münger, S. and Weinblum, L. in press 'The archaeological documentation system DANA (Digital Archaeology and National Archives): a view from the field' in U. Davidovich, S. Matskevich and N. Yahalom (eds) Material, Method, and Meaning. Papers in Eastern Mediterranean Archaeology in honor of Ilan Sharon, Münster: Zaphon.

Sharon, I. (ed) 2019 Tel Dor, Area G Report [dataset], Open Context. https://doi.org/10.6078/M7PG1PTT

Weinblum, L. and Münger, S. 2015 'DANA (Digital Archaeology and National Archives) a new software tool for field archaeologists' in S. Campana and R. Scopigno (eds) Keep the Revolution Going. 43rd Computer Applications and Quantitative Methods in Archaeology, Book of Abstracts, Siena: University of Siena. 46. 